\title{
An artificial neural network application to produce debris source areas of Barla, Besparmak, and Kapi Mountains (NW Taurids, Turkey)
}

\author{
M. C. Tunusluoglu ${ }^{1}$, C. Gokceoglu ${ }^{1}$, H. Sonmez ${ }^{1}$, and H. A. Nefeslioglu ${ }^{2}$ \\ ${ }^{1}$ Hacettepe University, Department of Geological Engineering, Applied Geology Division, 06532 Beytepe, Ankara, Turkey \\ ${ }^{2}$ General Directorate of Mineral Research and Exploration, Department of Geological Research, Remote Sensing Center, \\ 06520 Ankara, Turkey
}

Received: 19 June 2007 - Revised: 27 August 2007 - Accepted: 29 September 2007 - Published: 9 October 2007

\begin{abstract}
Various statistical, mathematical and artificial intelligence techniques have been used in the areas of engineering geology, rock engineering and geomorphology for many years. However, among the techniques, artificial neural networks are relatively new approach used in engineering geology in particular. The attractiveness of ANN for the engineering geological problems comes from the information processing characteristics of the system, such as nonlinearity, high parallelism, robustness, fault and failure tolerance, learning, ability to handle imprecise and fuzzy information, and their capability to generalize. For this reason, the purposes of the present study are to perform an application of ANN to a engineering geology problem having a very large database and to introduce a new approach to accelerate convergence. For these purposes, an ANN architecture having 5 neurons in one hidden layer was constructed. During the training stages, total 40000 training cycles were performed and the minimum RMSE values were obtained at approximately 10000 th cycle. At this cycle, the obtained minimum RMSE value is 0.22 for the second training set, while that of value is calculated as 0.064 again for the second test set. Using the trained ANN model at 10000th cycle for the second random sampling, the debris source area susceptibility map was produced and adjusted. Finally, a potential debris source susceptibility map for the study area was produced. When considering the field observations and existing inventory map, the produced map has a high prediction capacity and it can be used when assessing debris flow hazard mitigation efforts.
\end{abstract}

Correspondence to: C. Gokceoglu

(cgokce@hacettepe.edu.tr)

\section{Introduction}

In recent years, artificial neural networks (ANN) have been applied to many studies in engineering geology and geomorphology (Meulenkamp and Alvarez Grima, 1999; Singh et al., 2001; Zhang and Govindaraju, 2003; Lee et al., 2003a, b, 2004, 2006; Gomez and Kavzoglu, 2005; Ermini et al., 2005; Sarangi and Bhattacharya, 2005; Yesilnacar and Topal, 2005; Sonmez et al., 2006; Lee and Evangelista, 2006) because an ANN based prediction model has a high prediction capacity due to its high performance in the modeling of non-linear multivariate problems. For this reason, ANN has become an attractive and important tool for engineering geologists and geomorphologists because both engineering geological and geomorphological problems are generally non-linear and multivariate problems. One of these problems is to produce debris source maps because the debris materials are produced in mountainous regions with high slope gradients and to access all debris source locations is almost impossible. A typical example for such fields is the northern slopes of the BarlaBesparmak and Kapi Mountains of the Taurids Mountain belt in the western part of the Mediterranean region of Turkey. In this region, an important amount of debris deposits accumulate in channels at upper elevations and foot zones of the mountain slopes. When these debris materials in the channels at upper elevations are triggered by heavy rainfalls, some catastrophic debris flows occur in the region. For this reason, the wide interest in research on Quaternary deposits is west-central Anatolia is partly because slope avalanches pose a serious hazard to many populated areas and mountain resorts (Nemec and Kazanci, 1999). In Turkey, mass movements are one of the most hazardous natural processes. Recently, some international papers have been published on the

Published by Copernicus Publications on behalf of the European Geosciences Union. 


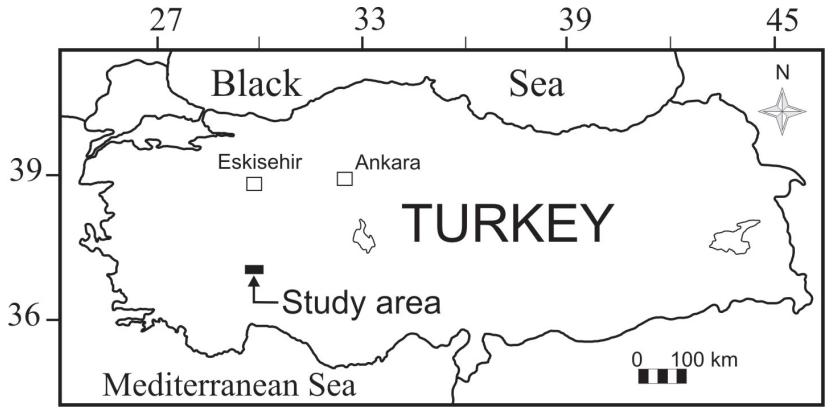

Fig. 1. Location map of the study area.

landslide mechanisms (Gokceoglu et al., 2005) and landslide susceptibility mapping (Gokceoglu and Aksoy, 1996; Can et al., 2005; Duman et al., 2006; Akgun and Bulut, 2007; Yalcin, 2007). However, these studies were applied in northern part of Turkey.

Although it is possible to find a number of recent publications on the various aspects of debris flow hazard (e.g., Rickenmann, 1999; Ishikawa et al., 2003; Jomelli et al., 2004; May and Greswell, 2004; Scally and Owens, 2004; Malet et al., 2004, 2005; Chien-Yuan et al., 2005; Garcin et al., 2005; Glade, 2005; Jakob, 2005; Wen and Aydin, 2005), no study was found in the literature on the assessment of debris source areas by artificial neural networks, except the study performed by Crowley et al. (2003). Crowley et al. (2003) analyzed potential debris flow source areas on Mount Shasta (California, USA) by using airborne and satellite remote sensing data. As mentioned earlier, determination of debris source areas by both field investigations and aerial photo interpretations is sometimes highly difficult because mountainous regions generally have extremely steep slopes, and moreover the scale of aerial photos does not allow such studies to be carried out. Considering these reasons, to produce a debris source area susceptibility map of the study area is the main purpose of the present study by artificial neural networks. For this purpose, the study is composed of two main stages such as compilation of the existing debris source area inventory map and application of artificial neural network analyses between the existing landslide inventory map and the geological and geomorphological parameters.

\section{General characteristics of the study area}

\subsection{Geology}

The study area is located at the connection point of West Taurids and Middle Taurids (Fig. 1). This region is also called the Lakes Region or the Isparta Triangle. The Isparta Triangle is bounded by Antalya Gulf and three lakes (the Burdur, Hoyran, and Beysehir Lakes). This region is composed of different rock associations based on stratigraphical and structural properties. Considering the purpose of this study and the areal extent of the study area, the Geyik Mountain and the Barla Mountain associations are briefly summarized in below, and the geological map of the study area is given in Fig. 2.

The relatively autochthonous Geyik Mountain unit, which extends as far as the long axis of the Taurides and constitutes the base line of the central Taurides, consists of an InfraCambrian, Cambrian, and Ordovician basement that is transgressively overlain by the Upper Paleozoic, Triassic, and Lower Jurassic clastics and carbonate rocks and by a platform type of a thick carbonate section of Jurassic to Lower Tertiary age that is bounded by Eocene flysch (Ozgul et al., 1991).

The Barla Mountains are bounded by the Senirkent plain to the north, Tertiary flysch of the Senirkent subunit to the west, the Isparta plain to the south, and Egirdir Lake to the east. The Barla Mountains, which are made up of a number of mountains and high hills, extend in an E-W direction. Length, width, and change of height of these mountains are $30 \mathrm{~km}, 10-12 \mathrm{~km}$, and $2400-2800 \mathrm{~m}$, respectively. The Barla Mountains subunit includes the sedimentary rock unit from the Upper Triassic to the Lower Eocene. The Ayazmana Formation, which is composed of sandstone and shale with reef limestone blocks, is the oldest rock unit of the Barla Mountains subunit that appears as an allochthon on the Senirkent unit. The Ayazmana Formation is overlain by the Norian-Rhaetian dolomites (Sariyer Dere dolomite) and Liassic limestones, which are rich in algea (Yassiviran limestone). The thickness of this formation is $\sim 500 \mathrm{~m}$ and includes abundant paleodasycladus. The Ayazmana Formation is overlain by the Dogger-Senonian pelagic deposition called as the Tinastepe Formation. Malm-Lower Cretaceous is assigned to micrite of flint nodules, pelagic foraminifera, and calsiturbidite (Ozgul et al., 1991).

\subsection{Climate}

The precipitation data is very important for such type analyses. For this reason, the precipitation data obtained from the Senirkent and Uluborlu meteorology stations located in the study area were employed. The region receives a longterm (1975-2004) average annual rainfall of over $54 \mathrm{~mm}$. A mass movement in the form of debris flow occurred in the town Senirkent on 13 July 1995. This disaster resulted in 74 deaths, and demolition and destruction of 180 buildings. Moreover, systems of communication, sewerage, drinking water, and electricity were considerably damaged. In addition, $\sim 1$ yr later, a new debris flow phenomenon occurred on 18 and 19 July 1996. However, because of warnings to local dwellings, no loss of life occurred. When making a close inspection to precipitation data recorded at the Senirkent and Uluborlu meteorology stations, the amount of the precipitation was very high. In other words, the values of total monthly precipitation recorded by the Senirkent meteorology station in July 1995 and July 1996 were 88.8 and 73.9 mm, 


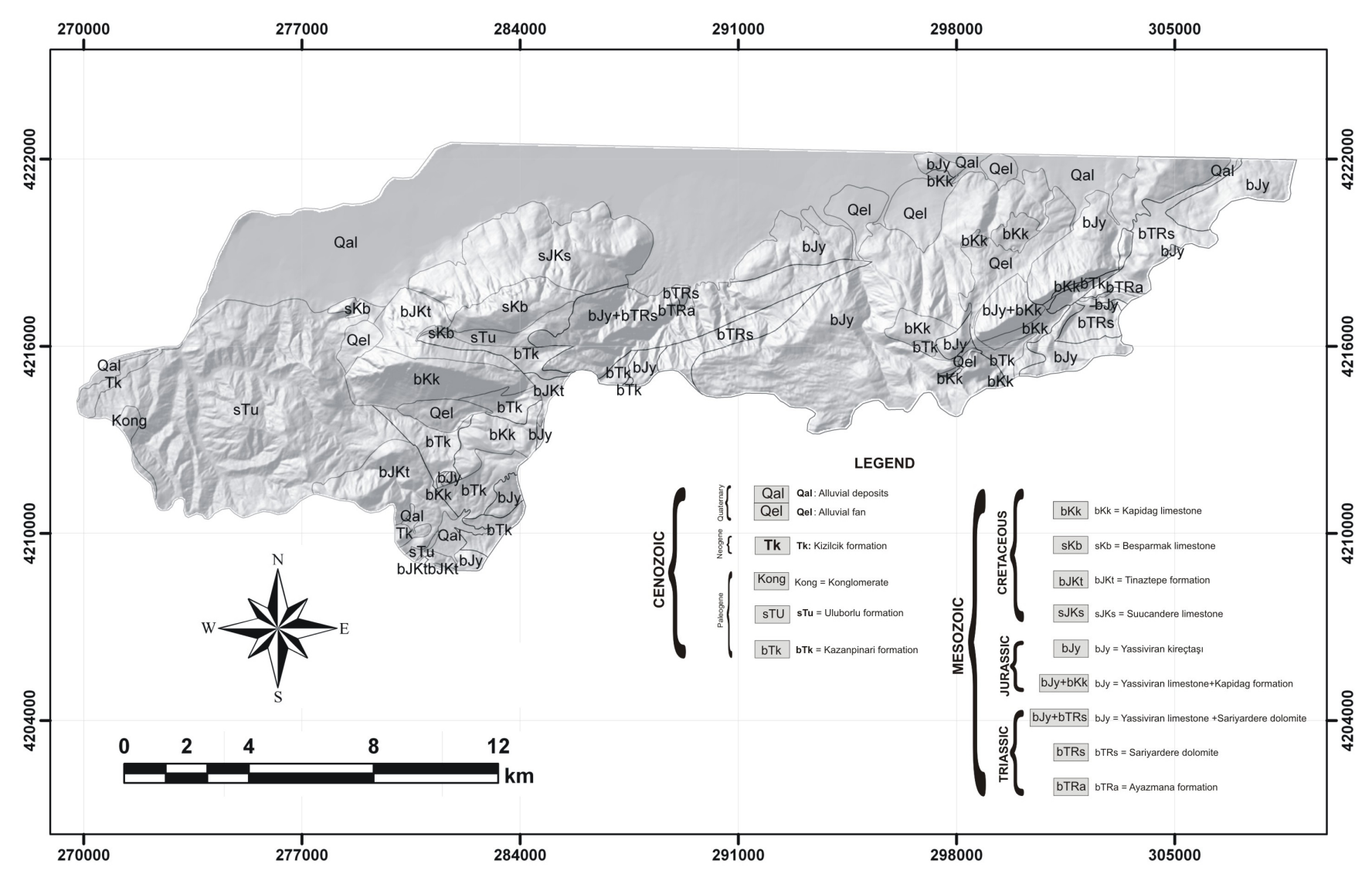

Fig. 2. Geological map of the study area.

respectively, while those recorded at the Uluborlu meteorology station were 79.6 and $105.2 \mathrm{~mm}$, respectively. Because the average monthly precipitation values over a long period of time are $16.6 \mathrm{~mm}$ in July for Senirkent and $21.8 \mathrm{~mm}$ in July for Uluborlu, the July 1995 and July 1996 precipitations can be considered as meteorological anomalies.

\section{Debris source inventory map}

The term "debris source area" can be described as a region having a potential to produce debris material. As mentioned earlier, the study area has mainly high altitudes and steep slopes. These characteristics do not allow us access everywhere in the area for field observation. For this reason, an extensive aerial photo interpretation was carried out to extract the possible debris source areas using vertical black and white aerial photographs of medium scale (1:35 000), dated in 1956 and 1991 (Tunusluoglu et al., 2007). In the study area, the debris material is produced by various limestones exposed in the study area. The frequency ratio table (Lee, 2005; Lee and Sambath, 2006) was prepared and given in Table 1. The Kapidag limestone, Kazanpinari Formation, Suucandere limestone, Besparmak limestone, Tinaztepe Forma- tion, Yassiviran limestone, Kapidag Formation and Uluborlu Formation have the potential for debris production (Table 1). However, in order to make an objective assessment for debris production potential of the lithological units, the following debris source intensity index (Eq. 1) is suggested by Tunusluoglu et al. (2007):

$\operatorname{DSI}_{i}=\frac{\operatorname{NPDS}_{i}}{A L_{i}}$

Where $\mathrm{DSI}_{i}$ is the debris source intensity of lithology I; $\mathrm{NPDS}_{i}$ is the number of pixels including debris source area of lithology I; and $A L_{i}$ is the total area of lithology $\mathrm{i}$ in the whole study area.

No vegetation cover is observed when the altitude is about higher than $2200 \mathrm{~m}$. In other words, the study area with an altitude of $2200 \mathrm{~m}$ or more is barren. This allows us to extract possible debris source areas with the aid of aerial photo interpretations. Identifying small source areas was almost impossible because of the scale of the aerial photos. However, the large areas were easily identified; and a debris source area inventory map was drawn (Fig. 3). During the second stage of the preparation of debris source inventory studies, an extensive field study was performed to check the findings obtained from aerial photo interpretations and to understand the 


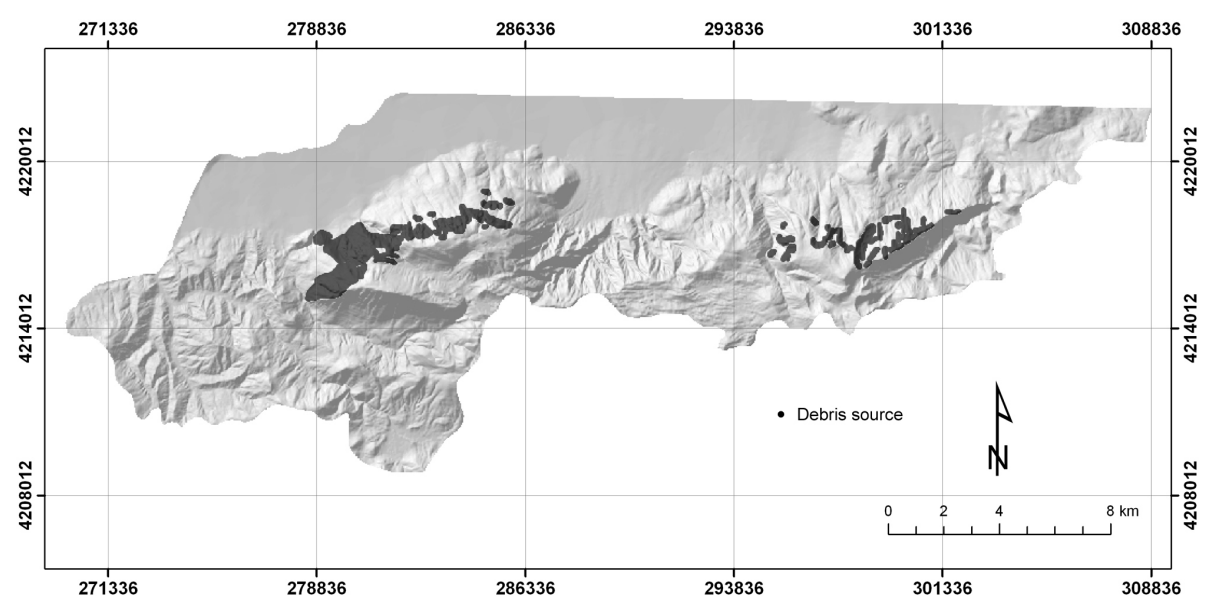

Fig. 3. Debris source inventory map of the study area.

mechanisms of debris generation (Tunusluoglu et al., 2007). The boundaries determined by aerial photo interpretations were checked by field investigations, and necessary corrections were done in the field at accessible locations. At not only higher elevations but also at lower elevations, the debris generation is observed. The possible causes of debris generation at lower elevations are the climate and topographic conditions. The climatic conditions governing debris generation prevail not only at higher elevations but also lower elevations in the region. Besides, transition between plain and mountain morphology is highly sharp. Hence, this results in a steep morphology at lower elevations. However, the debris source areas at these regions were not determined by aerial photo interpretations because of vegetation cover. The main source of the debris in the study area is the Besparmak limestone. However, a major structural control exists on the generation of debris. If the dip directions of slopes and bedding planes are parallel or nearly parallel to each other, no debris generation is observed. Dip of the bedding planes must be into the slope face for generation of debris. This situation results in a difficulty when preparing debris source area map because there is a major structural control on the generation of debris, and this control should be considered. An approach was introduced to overcome this difficulty by Tunusluoglu et al. (2007).

\section{Parameters contributing to debris generation}

When producing debris source areas susceptibility map, some geological and geomorphological parameters are required. For this reason, during the study, some index parameters such as stream power index (SPI), aspect, elevation, sediment transport capacity index (LS), plan curvature, profile curvature, and slope were considered (Fig. 4). As the terrain mapping unit, grid cell (pixel) having a spatial resolution of $25 \times 25 \mathrm{~m}$ was selected. The maps of all index parameters mentioned above were derived from digital elevation models (DEM) produced by digitizing 10-m altitude contours of the $1 / 25000$ scale topographical maps of the study area. The topographic elevations vary between $925-2800 \mathrm{~m}$ at the site. Statistical properties of each parameter were assessed into two groups such as: (i) pixels representing debris source areas and (ii) pixels representing free from debris source areas. While distribution of the topographic elevations free from debris source areas shows a similarity with the distribution of topographic elevations of whole area, the distribution of the pixels representing debris source area is quite different. This is an expected result because the debris source areas are generally located at upper elevations. One of the most important topographical parameters governing production of debris material is slope, because the debris material occurs at talus slopes. A talus slope can be described as an accumulation of rock debris at the base of a cliff or steep mountain slope and they generally show high gradients. For this reason, the slope map of the study area is produced. The slope angle values of the pixels representing debris source areas vary from 5 to 65 degrees while average of those is about 36 degrees. Contrary to this, the average values of slope angle of the pixels free from debris source areas is 16 degrees. This shows that the slope angle is one of the most representative topographical indicators for the assessment of debris source areas. The other DEM derived parameter employed in the study is aspect. Majority of the slopes free from debris source area in the area north-facing and limited number of pixels represent south-facing slopes (Table 1). The aspect map representing debris source areas has no south-facing slope. This indicates that the aspect is one of the main topographical attributes influencing the generation of debris material.

Slope curvatures were also investigated with respect to their effects on generation of debris material. The term curvature is generally defined as the curvature of a line formed by intersection of a random plane with the terrain surface. The curvature value can be evaluated calculating 
Table 1. Frequency ratios for different parameter classes with respect to debris source areas.

\begin{tabular}{|c|c|c|c|c|c|c|}
\hline $\begin{array}{l}\text { Parameter } \\
\text { Class }\end{array}$ & $\begin{array}{r}\text { the number of grid } \\
\text { cells on debris } \\
\text { source area }\end{array}$ & $(\%)$ & $\begin{array}{r}\text { the number of grid } \\
\text { cells on class }\end{array}$ & $(\%)$ & $\begin{array}{r}\text { Frequency } \\
\text { ratio }\end{array}$ & $\begin{array}{r}\text { DSI for lithology } \\
\text { classes }\end{array}$ \\
\hline \multicolumn{7}{|l|}{ Lithology } \\
\hline Kapidag limestone & 1434 & 14.23 & 26054 & 5.66 & 2.52 & 0.06 \\
\hline Kazanpinari fm. & 27 & 0.27 & 22639 & 4.92 & 0.05 & 0.00 \\
\hline Suucandere limestone & 1071 & 10.63 & 25034 & 5.44 & 1.95 & 0.04 \\
\hline Besparmak limestone & 1799 & 17.85 & 8028 & 1.74 & 10.24 & 0.22 \\
\hline Kizilcik fm. & 0 & 0.00 & 2990 & 0.65 & 0.00 & 0.00 \\
\hline Tinaztepe fm. & 3663 & 36.35 & 19552 & 4.25 & 8.56 & 0.19 \\
\hline Yassiviran limestone & 996 & 9.88 & 101876 & 22.12 & 0.45 & 0.01 \\
\hline $\begin{array}{l}\text { Yassiviran limestone }+ \\
\text { Kapidag fm. (not distinguished, bJy_bKk) }\end{array}$ & 627 & 6.22 & 4330 & 0.94 & 6.62 & 0.14 \\
\hline $\begin{array}{l}\text { Yassiviran limestone }+ \\
\text { Kapidag fm. (not distinguished, bJy_bTRs) }\end{array}$ & 0 & 0 & 22514 & 4.89 & 0 & 0 \\
\hline Ayazmana fm. & 0 & 0.00 & 635 & 0.14 & 0.00 & 0.00 \\
\hline Sariyardere dolomite & 0 & 0.00 & 17464 & 3.79 & 0.00 & 0.00 \\
\hline Konglomera & 0 & 0.00 & 1354 & 0.29 & 0.00 & 0.00 \\
\hline Alluvium & 31 & 0.31 & 111972 & 24.32 & 0.01 & 0.00 \\
\hline Cemented debris & 405 & 4.02 & 22977 & 4.99 & 0.81 & 0.02 \\
\hline Uluborlu fm. & 24 & 0.24 & 73059 & 15.87 & 0.02 & 0.00 \\
\hline \multicolumn{7}{|l|}{ Altitutde (m) } \\
\hline$<1100$ & 39 & 0.39 & 129513 & 28.13 & 0.01 & \\
\hline $1100-1300$ & 724 & 7.18 & 74747 & 16.23 & 0.44 & \\
\hline $1300-1500$ & 1119 & 11.10 & 65400 & 14.20 & 0.78 & \\
\hline $1500-1700$ & 1408 & 13.97 & 51571 & 11.20 & 1.25 & \\
\hline 1700-1900 & 2080 & 20.64 & 40037 & 8.69 & 2.37 & \\
\hline 1900-2100 & 2762 & 27.41 & 48864 & 10.61 & 2.58 & \\
\hline $2100-2300$ & 1496 & 14.85 & 32173 & 6.99 & 2.12 & \\
\hline $2300-2500$ & 428 & 4.25 & 13415 & 2.91 & 1.46 & \\
\hline 2500-2700 & 21 & 0.21 & 4415 & 0.96 & 0.22 & \\
\hline$>2700$ & 0 & 0.00 & 343 & 0.07 & 0.00 & \\
\hline \multicolumn{7}{|l|}{ Slope (degree) } \\
\hline$<10$ & 59 & 0.59 & 156867 & 34.07 & 0.02 & \\
\hline $10-20$ & 404 & 4.01 & 121656 & 26.42 & 0.15 & \\
\hline $20-30$ & 1750 & 17.37 & 112206 & 24.37 & 0.71 & \\
\hline $30-40$ & 4885 & 48.48 & 60772 & 13.20 & 3.67 & \\
\hline $40-50$ & 2452 & 24.33 & 7980 & 1.73 & 14.04 & \\
\hline $50-60$ & 496 & 4.92 & 961 & 0.21 & 23.59 & \\
\hline$>60$ & 31 & 0.31 & 36 & 0.01 & 39.35 & \\
\hline \multicolumn{7}{|l|}{ Aspect (degree) } \\
\hline Flat $(-1)$ & 0 & 0.00 & 11529 & 2.50 & 0.00 & \\
\hline $0-45$ & 2613 & 25.93 & 108927 & 23.66 & 1.10 & \\
\hline 45-90 & 482 & 4.78 & 53899 & 11.71 & 0.41 & \\
\hline 90-135 & 49 & 0.49 & 32375 & 7.03 & 0.07 & \\
\hline $135-180$ & 15 & 0.15 & 24866 & 5.40 & 0.03 & \\
\hline $180-225$ & 36 & 0.36 & 28532 & 6.20 & 0.06 & \\
\hline
\end{tabular}

the reciprocal value of the radius of curvature of the line. Hence, while the curvature values of broad curves are small, the tight ones have higher values. Plan curvature is described as the curvature of a contour line formed by intersection of a horizontal plane with the surface (Eq. 2) (Wilson and Gal- lant, 2000). The influence of plan curvature on the erosion processes is the convergence or divergence of water during downhill flow. In addition, this parameter constitutes one of the main factors controlling the geometry of the terrain surface where the debris material is accumulated. This can be 
Table 1. Continued.

\begin{tabular}{|c|c|c|c|c|c|}
\hline $\begin{array}{l}\text { Parameter } \\
\text { Class }\end{array}$ & $\begin{array}{r}\text { the number of grid } \\
\text { cells on debris } \\
\text { source area }\end{array}$ & $(\%)$ & $\begin{array}{r}\text { the number of grid } \\
\text { cells on class }\end{array}$ & $(\%)$ & $\begin{array}{r}\text { Frequency } \\
\text { ratio }\end{array}$ \\
\hline \multicolumn{6}{|l|}{ Aspect (degree) } \\
\hline $225-270$ & 474 & 4.70 & 30391 & 6.60 & 0.71 \\
\hline $270-315$ & 2649 & 26.29 & 54687 & 11.88 & 2.21 \\
\hline $315-360$ & 3759 & 37.30 & 115272 & 25.03 & 1.49 \\
\hline \multicolumn{6}{|c|}{ Plan curvature (rad/m) } \\
\hline$<(-1.0)$ & 1658 & 16.45 & 21473 & 4.66 & 3.53 \\
\hline$(-1)-(-0.5)$ & 1122 & 11.13 & 31045 & 6.74 & 1.65 \\
\hline$(-0.5)-(-0.1)$ & 1386 & 13.75 & 70337 & 15.27 & 0.90 \\
\hline$(-0.1)-0$ & 444 & 4.41 & 57394 & 12.46 & 0.35 \\
\hline $0-0.1$ & 522 & 5.18 & 123192 & 26.75 & 0.19 \\
\hline $0.1-0.5$ & 1644 & 16.31 & 98338 & 21.36 & 0.76 \\
\hline $0.5-1$ & 1417 & 14.06 & 39916 & 8.67 & 1.62 \\
\hline$>1.0$ & 1884 & 18.70 & 18783 & 4.08 & 4.58 \\
\hline \multicolumn{6}{|c|}{ Profile curvature (rad/m) } \\
\hline$<(-1.0)$ & 1376 & 13.65 & 14436 & 3.14 & 4.36 \\
\hline$(-1)-(-0.5)$ & 1353 & 13.43 & 36286 & 7.88 & 1.70 \\
\hline$(-0.5)-(-0.1)$ & 1861 & 18.47 & 85825 & 18.64 & 0.99 \\
\hline$(-0.1)-0$ & 563 & 5.59 & 52504 & 11.40 & 0.49 \\
\hline $0-0.1$ & 568 & 5.64 & 125573 & 27.27 & 0.21 \\
\hline $0.1-0.5$ & 1864 & 18.50 & 90634 & 19.68 & 0.94 \\
\hline $0.5-1$ & 1276 & 12.66 & 38258 & 8.31 & 1.52 \\
\hline$>1.0$ & 1216 & 12.07 & 16962 & 3.68 & 3.28 \\
\hline \multicolumn{6}{|c|}{ Stream power index } \\
\hline$<1.0$ & 4699 & 46.63 & 307053 & 66.68 & 0.70 \\
\hline $1.0-2.0$ & 2846 & 28.24 & 90027 & 19.55 & 1.44 \\
\hline $2.0-3.0$ & 1363 & 13.53 & 32999 & 7.17 & 1.89 \\
\hline $3.0-4.0$ & 473 & 4.69 & 13887 & 3.02 & 1.56 \\
\hline $4.0-5.0$ & 364 & 3.61 & 7883 & 1.71 & 2.11 \\
\hline$>5.0$ & 332 & 3.29 & 8629 & 1.87 & 1.76 \\
\hline \multicolumn{6}{|c|}{$\begin{array}{l}\text { Sediment transport capacity } \\
\text { index }\end{array}$} \\
\hline$<2.0$ & 2276 & 22.59 & 225841 & 49.04 & 0.46 \\
\hline $2.0-4.0$ & 402 & 3.99 & 74031 & 16.08 & 0.25 \\
\hline $4.0-6.0$ & 1535 & 15.23 & 57264 & 12.44 & 1.22 \\
\hline $6.0-8.0$ & 1564 & 15.52 & 37772 & 8.20 & 1.89 \\
\hline $8.0-10.0$ & 1225 & 12.16 & 23429 & 5.09 & 2.39 \\
\hline$>10.0$ & 3075 & 30.52 & 42141 & 9.15 & 3.33 \\
\hline
\end{tabular}

obviously realized when comparing the mean plan curvature values of the pixels representing debris source areas $(0.05)$ with pixels representing free from debris source areas $(0.01)$. The profile curvature is the curvature in the vertical plane parallel to the slope direction (Eq. 3) (Wilson and Gallant, 2000). It is the measure of the rate of change of slope. For this reason, this parameter directly controls velocity of water flow, and so erosion. While the values of minimum and maximum profile curvatures of debris source areas and the areas free from debris are $-7.08,8.42$, and $-9.35,10.95$, respectively, the mean profile curvature values are 0.01 for debris source area and -0.04 for the areas free from debris. This descriptive statistical evaluation suggests that the profile curvature parameter also strictly controls the zones of debris 
material accumulation.

$$
\begin{gathered}
K_{p}=\frac{\frac{\partial_{z}^{2}}{\partial_{x^{2}}}\left(\frac{\partial_{z}}{\partial_{x}}\right)^{2}+2\left(\frac{\partial_{z}^{2}}{\partial_{x} \partial_{y}}\right)\left(\frac{\partial_{z}}{\partial_{x}}\right)\left(\frac{\partial_{z}}{\partial_{y}}\right)+\frac{\partial_{z}^{2}}{\partial_{y^{2}}}\left(\frac{\partial_{z}}{\partial_{y}}\right)}{\left(\left[\left(\frac{\partial_{z}}{\partial_{x}}\right)^{2}+\left(\frac{\partial_{z}}{\partial_{y}}\right)^{2}\right]\left[\left(\frac{\partial_{z}}{\partial_{x}}\right)^{2}+\left(\frac{\partial_{z}}{\partial_{y}}\right)^{2}+1\right]\right)^{\frac{3}{2}}} \\
K_{c}=\frac{\frac{\partial_{z}^{2}}{\partial_{x^{2}}}\left(\frac{\partial_{z}}{\partial_{y}}\right)^{2}-2\left(\frac{\partial_{z}^{2}}{\partial_{x} \partial_{y}}\right)\left(\frac{\partial_{z}}{\partial_{x}}\right)\left(\frac{\partial_{z}}{\partial_{y}}\right)+\frac{\partial_{z}^{2}}{\partial_{y^{2}}}\left(\frac{\partial_{z}}{\partial_{x}}\right)^{2}}{\left[\left(\frac{\partial_{z}}{\partial_{x}}\right)^{2}+\left(\frac{\partial_{z}}{\partial_{y}}\right)^{2}\right]^{\frac{3}{2}}}
\end{gathered}
$$

Primary topographical attributes such as aspect, slope and slope curvatures are calculated directly from the derivatives of a topographic surface (Wilson and Gallant, 2000). On the other hand, the secondary topographical attributes are computed from two or more primary attributes. According to Wilson and Gallant (2000), the majority of these secondary attributes comes from the ability of describing patterns as a function of process. In this study, two well-known secondary topographical attributes were also evaluated. One of the secondary topographical attributes used in this study is stream power index (SPI). It is a measure of erosive power of water flow based on assumption that discharge $(q)$ is proportional to specific catchment area $\left(A_{S}\right)($ Eq. 4) (Moore et al., 1991).

$$
\mathrm{SPI}=A_{s} \tan \beta
$$

where, $A_{s}$ is the specific catchment area $\left(\mathrm{m}^{2} \mathrm{~m}^{-1}\right), \beta$ is the slope gradient in degree. The index, SPI, is one of the main factors controlling the erosion processes. Besides, the erosion processes can be considered as one of the main component of the generation of debris material. Descriptive statistical evaluations suggest that particularly the mean values of SPI for debris source areas (1.42) and for areas free from debris (0.93), the importance of the index SPI in generation of debris material is comprehensible.

The other secondary topographical attribute used in this study is the sediment transport capacity index (LS) (Moore and Burch, 1986). The calculation of LS value is given in the equation below:

$$
\mathrm{LS}=(m+1)\left(A_{s} / 22.13\right)^{m}(\sin \beta / 0.0896)^{n}
$$

where $A_{s}$ is the specific cathment area $\left(\mathrm{m}^{2} \mathrm{~m}^{-1}\right), \beta$ is the slope gradient (in degrees), values of $m$ and $n$ are 0.4 and 1.3, respectively (Moore and Wilson, 1992). This parameter was derived from unit stream power theory and is equivalent to the length-slope factor in the revised universal soil loss equation in certain circumstances where slope length $<100 \mathrm{~m}$ and slope $<14^{\circ}$ (Moore and Wilson, 1992). However, these conditions could not be satisfied in this study due to the morphological characteristics of the study area. As mentioned previously, the secondary topographical attributes such as LS are the functions of surface processes. Depending on the increase of slope gradient and specific catchment area, the LS
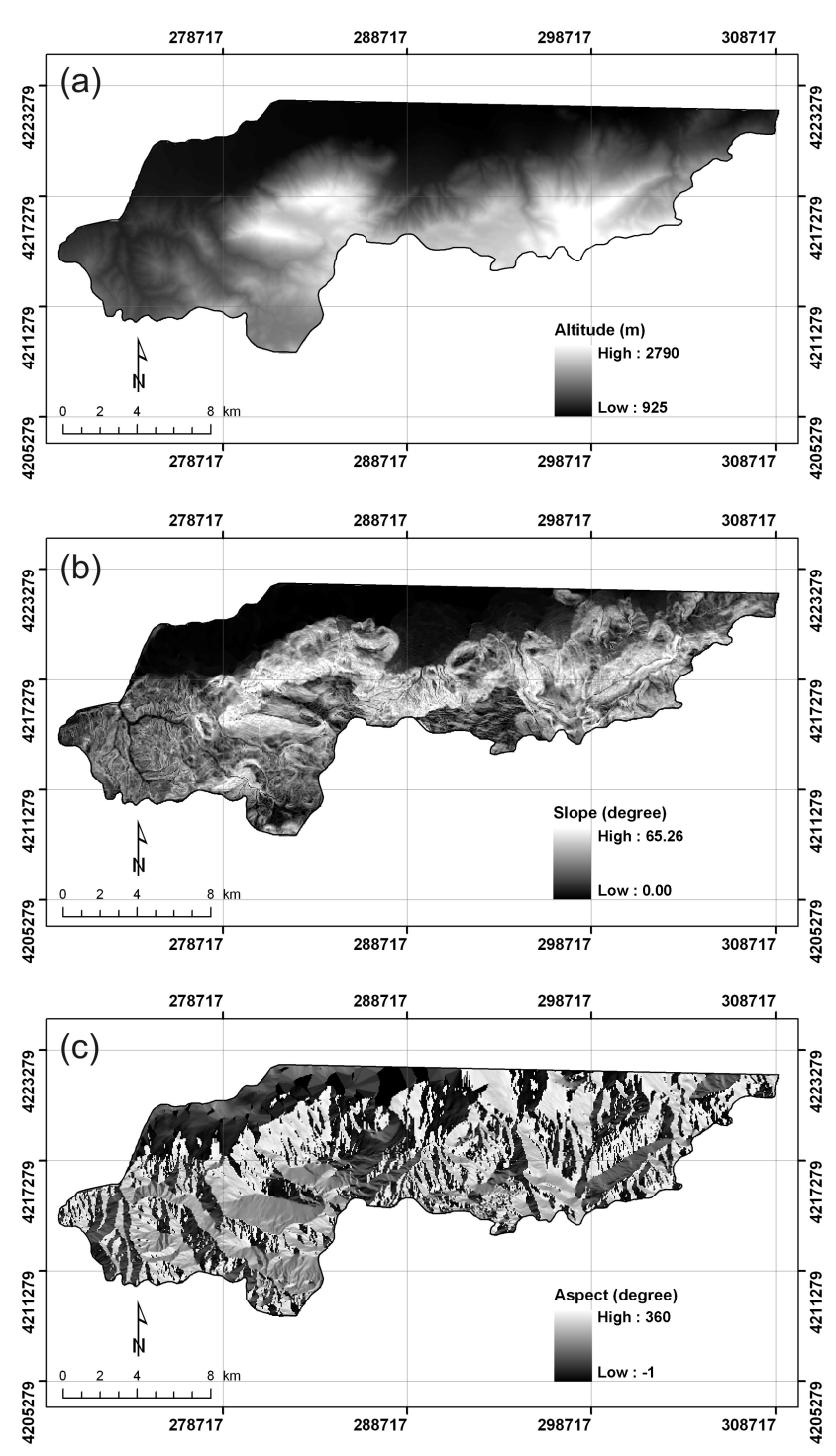

Fig. 4. Topographical parameter maps of the study area; Altitude (a), slope gradient (b), aspect (c), plan curvature (d), profile curvature (e), stream power index (f) and sediment transport capacity index (g).

will increase. Obviously, this high energy environment contributes disintegration of slope-forming rock. The mean values of LS of debris source areas and areas free from debris are 9.4 and 3.85, respectively. These descriptive statistics also indicate that LS is a useful parameter in differentiating debris sources.

\section{Application of ANN architecture to produce potential debris source area map}

In engineering geology and geomorphology literature, an ANN architecture have been used for different purposes, 

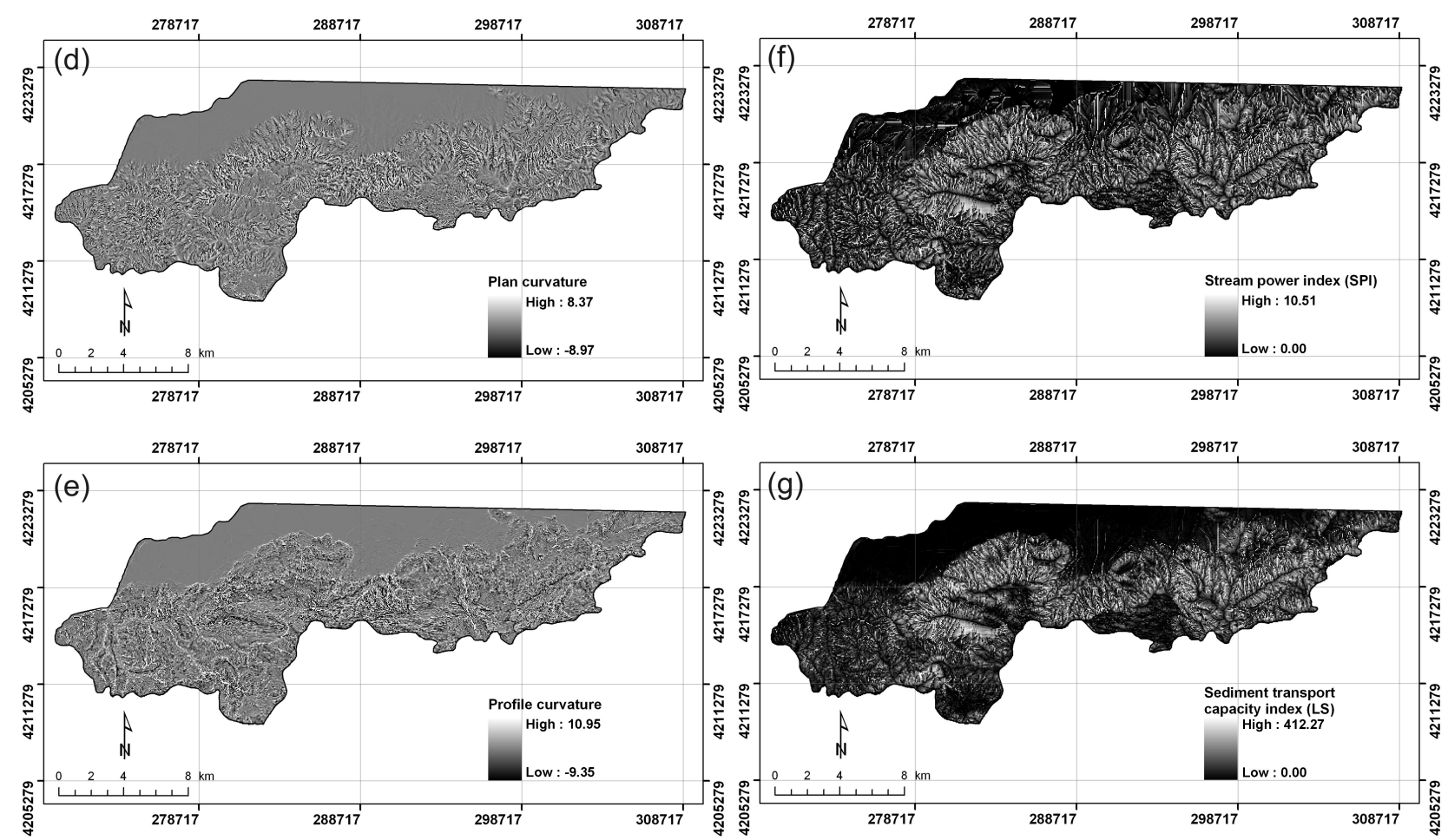

Fig. 4. Continued.

however parameter estimation and landslide susceptibility mapping are the most popular among the ANN applications (Singh et al., 2001; Lee et al., 2003; Gomez and Kavzoglu, 2005; Ermini et al., 2005; Yesilnacar and Topal, 2005; Sonmez et al., 2006).

The first stage in the application of the ANN architecture is the production of data matrix. While each row data represents an individual case expressed using a terrain mapping unit (grid cell), columnar data show the input and output variables in the data matrix. In this matrix, continuous variables (SPI, aspect, altitude, LS, plan curvature, profile curvature and slope) were normalized in the range of $[0,1]$. Since the parameter of geology is a categorical data, it was expressed in binary format with respect to each lithological definition. By considering 7 continuous variables and 15 lithological units in binary format, total 22 independent variables were included in the ANN architecture. Output variable of the analysis is also expressed in binary format with respect to presence (1) and absence (0) of debris material.

A neural network model of the data-generating system can be constructed using an artificial neural network (ANN), the network predicting outputs from inputs. Hecht-Nielsen (1987) and Schalkoff (1997) indicate that an ANN may be defined as a structure comprised of densely interconnected adaptive simple processing elements that are capable of performing massively parallel computations for data processing and knowledge representation.
The attractiveness of ANN comes from the information processing characteristics of the system, such as nonlinearity, high parallelism, robustness, fault and failure tolerance, learning, ability to handle imprecise and fuzzy information, and their capability to generalize (Jain et al., 1996). ANN-based models are also empirical in nature; however, they can provide practically accurate solutions for precisely or imprecisely formulated problems and for phenomena that are only understood through experimental data and field observations (Basheer and Ajmeer, 2000).

Several types of ANN have been used in the literature. However, the back-propagation ANN, which is also known as the generalized delta rule, is the most popular one. A back-propagation network is a multi-layer neural network $(\mathrm{MNN})$. The MNN with back-propagation (BMNN) has been successfully used as a mapping and prediction tool in the engineering geology. Neaupane and Achet (2004), Lee et al. (2004), Gomez and Kavzoglu (2005), Ermini et al. (2005) and Yesilnacar and Topal (2005) are some examples for landslide susceptibility mapping applications of BMNN. The back-propagation technique has expanded the range of problems to which ANNs can be applied, and it has generated many successful demonstrations of its power (Neaupane and Achet, 2004). The simplest form MNN is composed of one input layer and one output layer. The complexity of the MNN structure increases by the addition of a hidden layer. Each layer consists of neurons (nodes), and the neurons are 
connected by weighted links passing signals from one neuron to another. The final weights and thresholds of activation for decreasing the error between observed and computed outputs subject to a sufficient level defined by the user is set in the training phase of the ANN algorithm.

The transfer function, also called the activation function, is necessary to transform the weighted sum of all signals impinging on a neuron so as to determine its firing intensity (Basheer and Hajmeer, 2000). The most common transfer function implemented in the literature is the sigmoid function. Therefore, the sigmoid function is preferred as the transfer function in this study. The forward and backward stages are performed repeatedly until the neural network solution reaches the predefined threshold for the root mean square error (RMSE).

Kavzoglu (2001) pointed out that a sufficient number of training samples being available is important to estimate these parameters accurately. For this purpose, Klimasauskas (1993) and Messer and Kittler (1998) suggested that at least 5-10 times the number of training samples as free parameters (weights) should be used. While Swingler (1996) and Looney (1996) proposed $20 \%$ and $25 \%$ of the data for testing, respectively, Nelson and Illingworth (1990) recommend between $20 \%$ and $30 \%$ of data for testing. However, Kavzoglu (2001) proposed that the optimal number of training samples must be between $[30 \times$ numbers of input nodes $\times$ (numbers of input nodes+1)] and $[60 \times$ numbers of input nodes $\times$ (numbers of input nodes +1$)]$. When considering the approach proposed by Kavzoglu (2001), the number of dataset should be between 15180 and 30360 . In this study, total 10077 pixels are included by the debris source areas in the debris source inventory map. $20 \%$ of this amount were selected randomly, and assigned as the test data set. Considering the rest of the presence data having 8062 pixels in spatial domain, the same amount of cases were picked up randomly from the grid cells without debris source area. Hence, a training data set contains total 16124 cases, while a test data set includes 2015 grid cells. As a consequence, the number of dataset used in the model training can be considered as acceptable. In this study, to check the generalization capacity of the constructed ANN structure, three different random data sets produced applying the sampling procedure given above.

The initial weights, learning rate $(\eta)$ and momentum coefficients $(\mu)$ of the ANN influence the convergence of the back-propagation learning rule (Basheer and Hajmeer, 2000; Yesilnacar and Topal, 2005). In the literature, the initial weights are generally set as random small values. Different ranges were used to set the initial weights: such as [ $-0.1 ; 0.1]$ by Paola (1994) and Staufer and Fisher (1997); [ $-0.25 ; 0.25]$ by Gallahger and Downs (1994) and Kavzoglu (2001); [ $-0.3 ; 0.3]$ by Rumelhart et al. (1986) and ASCE (2000); and [-0.5;0.5] by Sietsma and Dow (1991) and Looney (1997). Fahlman (1988) stated that initialization of the weights has an insignificant effect on both the conver-

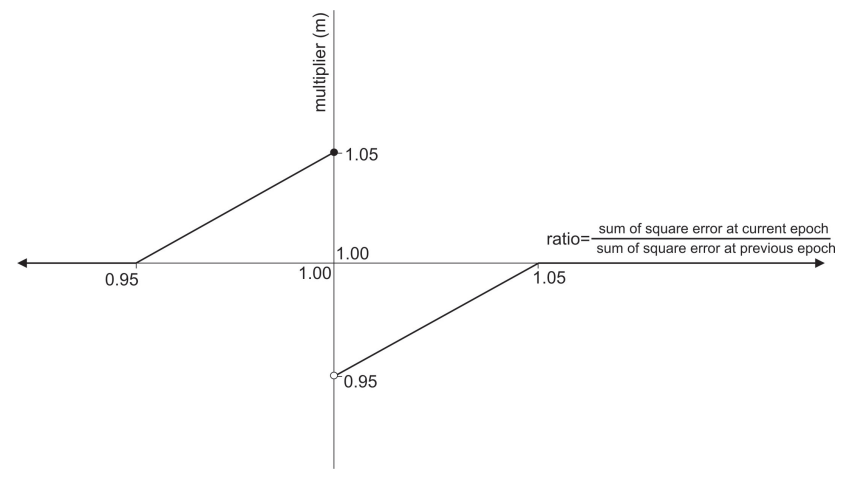

Fig. 5. The approach of the calculation of dynamic learning rate.

gence and final network architecture. However, Basheer and Hajmeer (2000) indicated that too small a range can lead to small error gradients which may slow down the initial learning process. In this study, the initial weight range was randomly selected between -1.0 and 1.0.

The learning rate $(\eta)$ and momentum coefficient $(\mu)$ plays important role on the time consuming during the training phase of ANN. The training rate may be slow for very small learning rate because of minor changes to weights in the network due to small $\eta$ values. On the other hand, training phase can be oscillated when $\eta$ is selected to large. In this study, to accelerate the convergence, dynamic learning rate was preferred instead of constant unique value. For this purpose, a new approach for dynamic learning rate was introduced by using the heuristic proposed by Negnevitsky (2002). In the heuristic suggested by Negnevitsky (2002) a multiplier is selected to increase or decrease the learning rate. If the sum of square errors at the current epoch exceed the previous value by more that a predefined value (typically 1.04), the learning rate parameter is decreased (typically by multiplying by 0.7 ), on the contrary, if the error is less than the previous one learing rate is increased (typically by multiplying by 1.05 ) according to the heuristic proposed by Negnevitsky (2002). A function for multiplier in the range of predefined ratio of the sum of square errors obtained current to previous epochs was preferred instead of constant value in the approach introduced in this study. The approach is explained in Fig. 5, and given by Eq. (6).

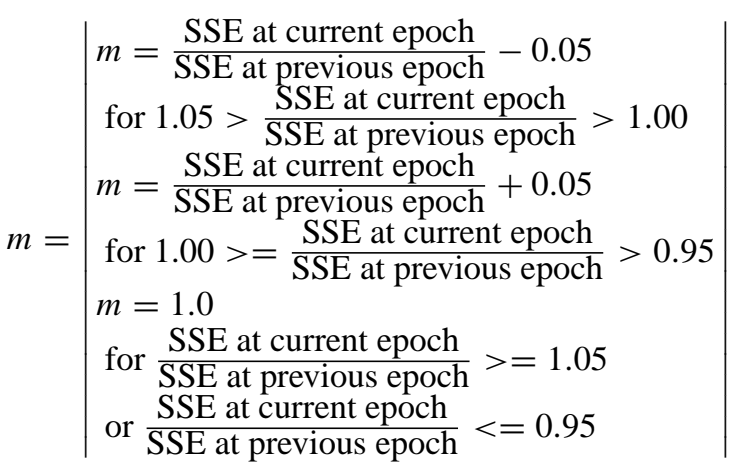




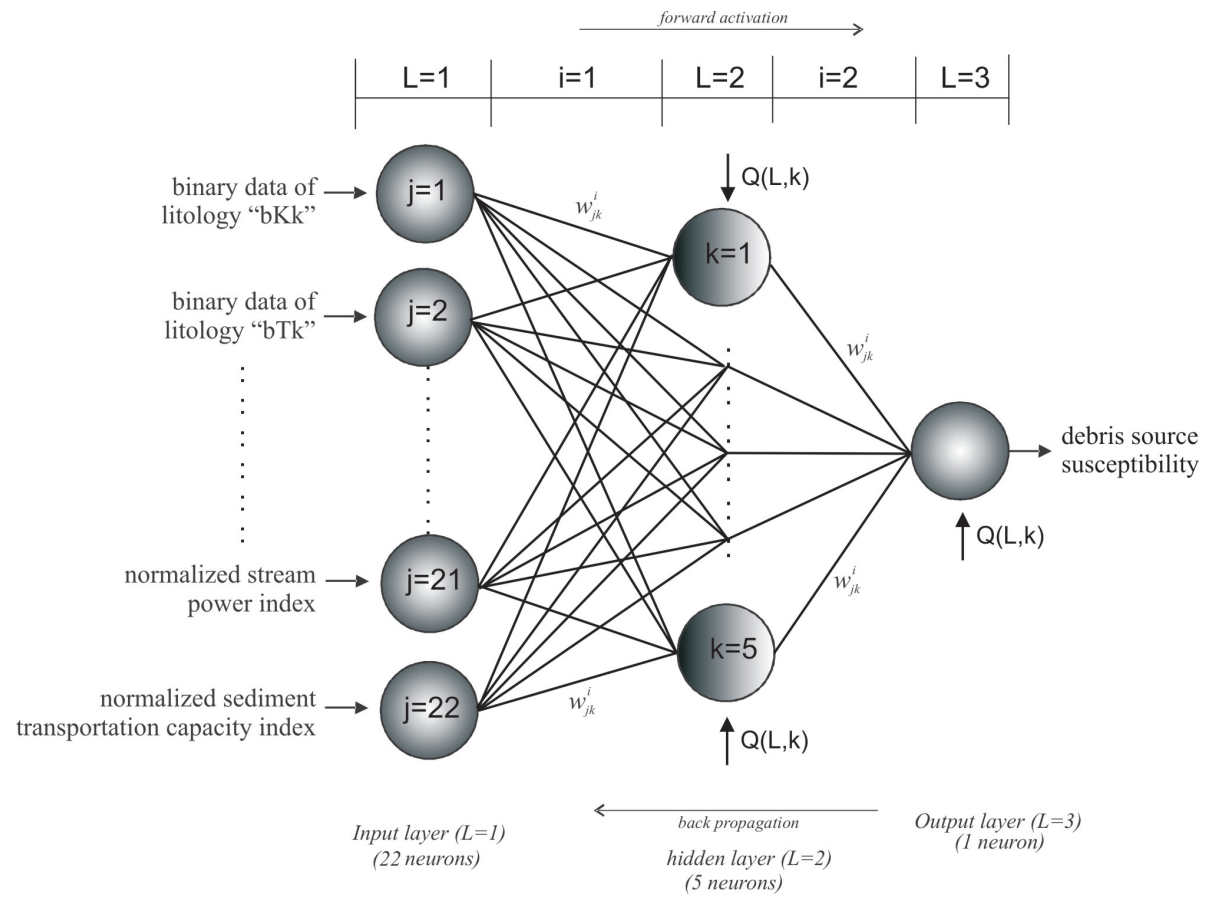

Fig. 6. Artificial neural network structure used in this study.
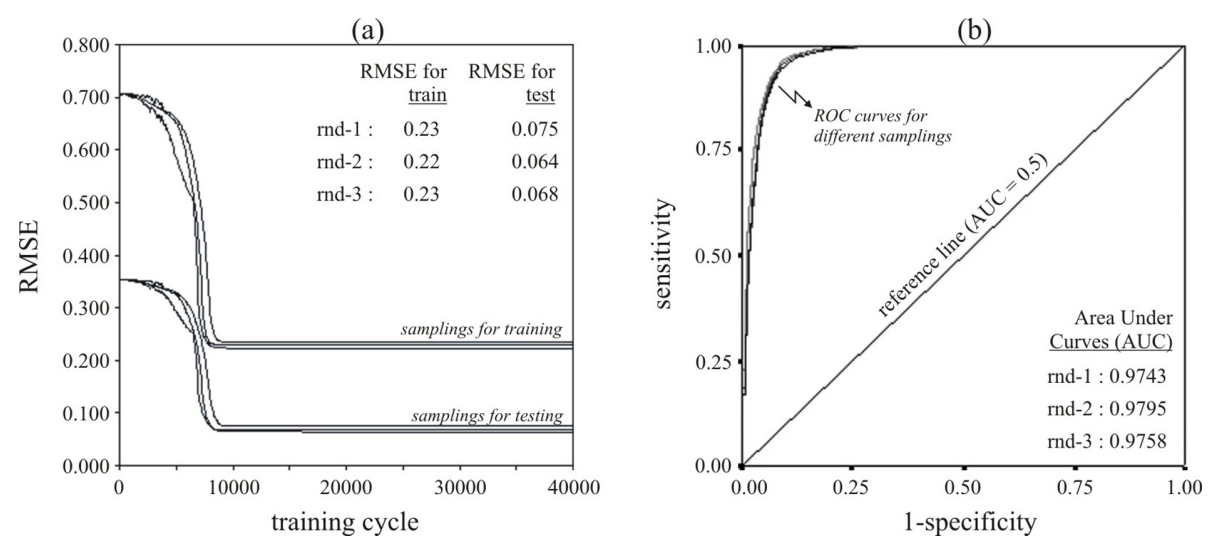

Fig. 7. The relations between the number of the training cycles and RMSE values for the training and the test data sets (a), and ROC curve evaluations for entire study area.

$\eta_{\text {for next epoch }}=m x \eta_{\text {at current epoch }}$

where $m$ is multiplier, SSE is sum of square error, $\eta$ is learning rate. Negnevitsky (2002) indicated that the momentum coefficient has stabilizing effect in the back-propagation algorithm. The momentum coefficient was set between 0.4 and 0.9 by Wyhthoff (1993), Hassoun (1995) and Fu (1995) suggests a value between 0.0 and 1.0, and Henseler (1995) and Hertz et al. (1991) suggest $\mu \cong 1.0$. In this study, the momentum coefficient was set to 0.95 by considering the values suggested in the literature.

Selection of the number of neurons is one of the most critical tasks in the ANN structure. In the literature, it is possi- ble to find many heuristic approaches for the selection of the number of hidden neurons. These were summarized by Kavzoglu (2001). In this study, the heuristic approach proposed by Kaastra and Boyd (1996) was employed because this approach gives minimum number of hidden layers among the approaches proposed for the selection of the number of hidden layers. In this study, the numbers of input and dataset are very large. As a result of the heuristic approach proposed by Kaastra and Boyd (1996), total 5 neurons in one hidden layer were obtained for the model employed in this study (Fig. 6).

The ANN structures were trained by using combinations of learning rates and the number of hidden neurons defined 


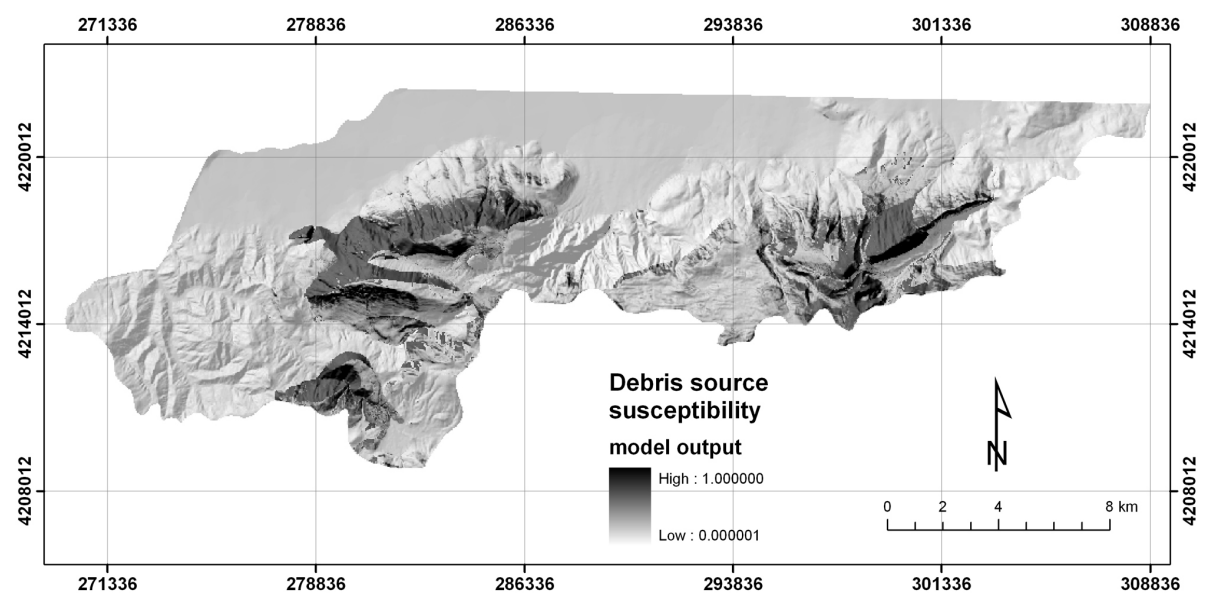

Fig. 8. Potential debris source susceptibility map.

above. The datasets were normalized between zero and 1 considering the maximum values of input variables. In this study, a computer code, namely ANNES written by Sonmez et al. (2006) was used to construct the ANN structure. The relation between the number of training cycles and the RMSE values of the models obtained by ANNES for each random data set are given in Fig. 7. During the training stages, total 40000 training cycles were performed and the minimum RMSE values were obtained at approximately 10000 th cycle. At this cycle, the obtained minimum RMSE value is 0.22 for the second training set, while that of value is calculated as 0.064 again for the second test set (Fig. 7a).

Using the trained ANN model at 10000 th cycle for the second random sampling, the debris source area susceptibility map was produced and given in Fig. 8. Considering the receiver operating characteristic curves (ROC) and the area under curve (AUC) values, the more spatially effective map was achieved by using the second random sampling (Fig. 7b). However, as can be seen from Fig. 8, the produced map is conservative when considering the field observations. The similar observations were also carried out by Tunusluoglu et al. (2007). The main reasons and a proposal were given by Tunusluoglu et al. (2007). There is a considerable structural control on debris generation in the study area. In other words, if slope aspect and orientation of bedding planes are same in the region, no debris generation occurs. However, this situation was not detected by aerial-photo interpretations due to scale of the aerial photos and vegetation cover at some parts of the study area. For this reason, a structural adjustment for the debris source area susceptibility map is needed. Since it was observed that all debris generation occurs on the geomorphologic units of cuestas, it can be considered that all debris source areas mapped during field studies coincided with the geomorphologic units of cuestas. Consequently, this situation constitutes the main assumption of the approach proposed for the structural adjustment for the susceptibility map of potential debris source area in this study (Tunusluoglu et

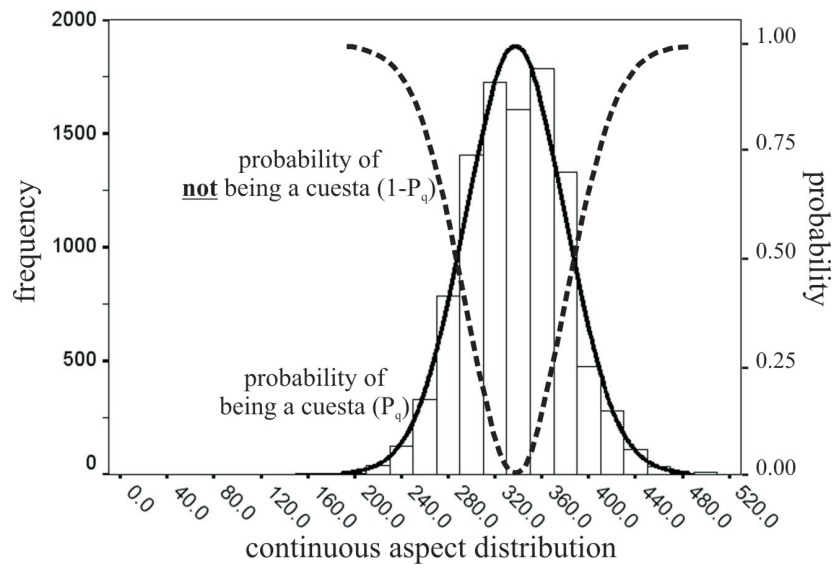

Fig. 9. Continuous aspect distribution (Tunusluoglu et al., 2007).

al., 2007). The second assumption is that theoretical probability distribution of slope aspect values of debris source areas is equal to the theoretical probability distribution of being a cuesta in the field. If $P_{q}$ is the probability of being a cuesta, $1-P_{q}$ is the probability of not being a cuesta. To calculate the adjusted probability $\left(P_{d}^{\prime}\right)$ of being a debris source area at a point in the field, $1-P_{q}$ (the probability of not being a cuesta) is subtracted from the probability $\left(P_{d}\right)$ value of being a debris source area. Calculation of the value " $1-P_{q}$ " (the probability of not being a cuesta) has three main stages. First stage is the construction of the theoretical probability distribution of slope aspect values of debris source areas. However, due to the categorical nature of slope aspect values, a transformation is needed to obtain the continuous slope aspect distribution. For example, value of -1 in the slope aspect values does not mean orientation information. It means flat areas in the field. Hence, this value should be excluded from the distribution. In addition, the value " 0 " and the value "360" in the slope aspect distribution are equal with 


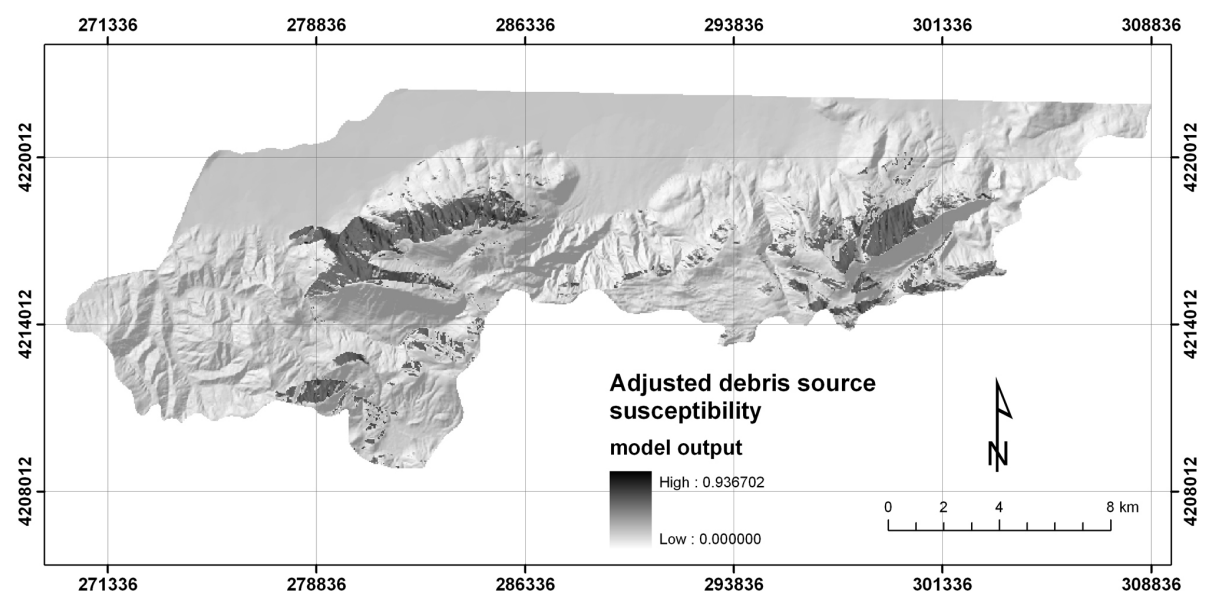

Fig. 10. Adjusted potential debris source susceptibility.

respect to orientation information. So, the transition from " 0 " to "360" should be removed (second stage). For this purpose, the slope aspect values in the range of $[0,157]$ were summed with the value 360 . The new distribution which shows almost an ideal theoretical normal distribution (Fig. 9) is obtained in the range of $[165,514]$. The mean and the standard deviation values of this distribution are 337.32 and 42.59, respectively (Tunusluoglu et al., 2007). As a result, the probability density function of this distribution can be written as follows.

$$
f(x)=[1 / 42.59 \sqrt{ }(2 \pi)] \exp \left(-\left[1 /(3628.04)(x-337.32)^{2}\right]\right)
$$

For the last stage, using Eq. (4), the probability values of being a cuesta were calculated (the value " $P_{q}$ "). Then, to obtain the probability values of not being a cuesta, these " $P_{q}$ " values were subtracted from 1 . To obtain the adjusted probability $\left(P_{d}^{\prime}\right)$ values of being a debris source area, the values " $1-P_{q}$ " was subtracted from the probability values of debris source areas. Finally, adjusted potential debris source area map is obtained (Fig. 10) by using the adjusted probability values. The adjusted map was not classified into subclasses and the map was given as continuous scale. However, to make a general assessment, it may be classified into three sub-classes such as low (0-0.4), moderate (0.4-0.6) and high (0.6-1). The percent areal extensions of low, moderate and high susceptibility classes are found as $93.3 \%, 3.0 \%$ and $3.7 \%$, respectively. The field observations revealed that the final adjusted susceptibility map exhibits a high performance, and it can be used for debris flow hazard assessments to be performed at this site in future.

\section{Results and conclusions}

The following results and conclusions can be drawn from the present study:

1. In this study, an ANN architecture having five neurons in one hidden layer was constructed to obtain po- tential debris source susceptibility map of the northern slopes of the Barla - Besparmak and Kapi Mountains of the Taurids Mountain belt in the western part of the Mediterranean region of Turkey. In this region, an important amount of debris deposits accumulate in channels at upper elevations and foot zones of the mountain slopes. When these debris materials in the channels at upper elevations are triggered by heavy rainfalls, some catastrophic debris flows occur in the region, and these catastrophic mass movements result in loss of lives, environmental hazards and economical losses.

2. The produced map show a considerable performance and it can be used for debris flow hazard mitigation efforts. To make a general assessment on the produced map and the study area, the map was classified into three sub-classes such as low (0-0.4), moderate (0.4-0.6) and high (0.6-1). The percent areal extensions of low, moderate and high susceptibility classes are found as $93.3 \%$, $3.0 \%$ and $3.7 \%$, respectively.

3. A new approach for dynamic learning rate introduced in this study to accelerate convergence should be investigated for different database having varied volume of data. The needed improvement to the new approach for dynamic learning rate could be employed.

Acknowledgements. This research is supported by TUBITAK (The Scientific and Technological Research Council of Turkey) with a project number of 103Y144. The authors thank to R. Ulusay and Z. A. Erguler for his supports during the field investigations.

Edited by: T. Glade

Reviewed by: L. Saro and T. van Asch

\section{References}

Akgun, A. and Bulut, F.: GIS-based landslide susceptibility for Arsin-Yomra (Trabzon, North Turkey) region, Environmental 
Geology, 51, 1377-1387, 2007.

ASCE: Artificial neural networks in hydrology: I. Preliminary concepts. J. Hydrol. Eng., 5, 115-123, 2000.

Basheer, I. A. and Hajmeer, M.: Artificial neural networks: fundamentals, computing, design, and application, J. Microbiol. Methods, 43, 3-31, 2000.

Can, T., Nefeslioglu, H. A., Gokceoglu, C., Sonmez, H., and Duman, T. Y.: Susceptibility assessments of shallow earthflows triggered by heavy rainfall at three subcatchments by logistic regression analyses, Geomorphology, 72, 250-271, 2005.

Chien-Yuan, C., Tien-Chien, C., Fan-Chieh, Y., Wen-Hui, Y., and Chun-Chieh, T.: Rainfall duration and debris flow initiated studies for real-time monitoring, Environmental Geology, 47, 715724, 2005.

Crowley, J. K., Hubbard, B. E., and Mars, J. C.: Analysis of potential debris flow source areas on Mount Shasta, California, bu using airborne and satellite remote sensing data, Rem. Sens. Environ., 87, 345-358, 2003.

Duman, T. Y., Can, T., Gokceoglu, C., Nefeslioglu, H. A., and Sonmez, H.: Application of logistic regression for landslide susceptibility zoning of Cekmece Area, Istanbul, Turkey, Environ. Geology, 51, 241-256, 2006.

Ermini, L., Catani, F., and Casagli, N.: Artificial Neural Networks applied to landslide susceptibility assessment, Geomorphology, 66, 327-343, 2005.

Fahlman, S. E.: An empirical study of learning speed in backpropagation, Technical Report CMU-CS-88-162, Carnegie-Mellon University, 1988.

Fu, F.: Neural Networks in Computer Intelligence, McGraw-Hill, New York, 460 pp., 1995.

Gallahger, M. and Downs, T.: Visualisation of learning in neural networks using principal component analysis, in: Proc of Int Conf on Computational Intelligence and Multimedia Applications, edited by: Varma, B. and Yao, X., Australia, 327-331, 1997.

Garcin, M., Poisson, B., and Pouget, R.: High rates of geomorphological processes in a tropical area: Remparts River case study (Reunion Island, Indian Ocean), Geomorphology, 67, 335-350, 2005.

Glade, T.: Linking debris-flow hazard assessments with geomorphology, Geomorphology, 66, 189-213, 2005.

Gokceoglu, C. and Aksoy, H.: Landslide susceptibility mapping of the slopes in the residual soils of the Mengen region (Turkey) by deterministic stability analyses and image processing techniques, Eng. Geol., 44, 147-161, 1996.

Gokceoglu, C., Sonmez, H., Nefeslioglu, H. A., Duman, T. Y., and Can, T.: The 17 March 2005 Kuzulu landslide (Sivas, Turkey) and landslide-susceptibility map of its near vicinity, Eng. Geology, 81, 65-83, 2005.

Gomez, H. and Kavzoglu, T.: Assessment of shallow landslide susceptibility using artificial neural networks in Jabonosa River Basin, Venezuela, Eng. Geology, 7, 11-27, 2005.

Hassoun, M. H.: Fundamentals of Artificial Neural Networks, MIT Press, Cambridge MA, USA, 537 pp., 1995.

Hecht-Nielsen, R.: Kolmogorov's mapping neural network existence theorem. Poc of the First IEEE International Conference on Neural Networks, San Diego CA, USA, 11-14, 1987.

Henseler, J.: Backpropagation, in: Artificial neural networks, an introduction to ANN theory and practice, edited by: Braspenning,
P. J., Lecture Notes in Computer Science, Berlin, Springer, 3766, 1995.

Hertz, J., Krogh, A., and Palmer, R. G.: Introduction to the Theory of Neural Computation, Addison-Wesley, Reading MA, 1991.

Ishikawa, Y., Kawakami, S., Morimoto, C., and Mizuhara, K.: Suppression of debris movement by forests and damage to forests by debris deposition, J. Forest Res., 8, 37-47, 2003.

Jain, A. K., Mao, J., and Mohiddin, K. M.: Artificial neural networks: a tutorial, Comput. IEEE March, 31-44, 1996.

Jakob, M.: A size classification for debris flows, Eng. Geology, 79, 151-161, 2005.

Jomelli, V., Pech, V. P., Chochillon, C., and Brunstein, D.: Geomorphic variations of debris flows and recent climatic change in the French Alps, Clim. Change, 64, 77-102, 2004.

Kaastra, I. and Boyd, M.: Designing a neural network for forecasting financial and economic time series, Neurocomputing, 10(3), 215-236, 1996.

Kavzoglu, T.: An investigation of the design and use of feedforward artificial neural Networks in classification of remotely sensed images, $\mathrm{PhD}$ Thesis, The University of Nottingham, UK (unpublished), 2001.

Klimasauskas, C. C.: Applying neural networks, in: Neural Networks in Finance and Investigating, edited by: Trippi, R. R. and Turban, E., Probus, Cambridge, 1993.

Lee, S. and Evangelista, D. G.: Earthquake-induced landslidesusceptibility mapping using an artificial neural network, Nat. Hazards Earth Syst. Sci., 6, 687-695, 2006, http://www.nat-hazards-earth-syst-sci.net/6/687/2006/.

Lee, S., Ryu, J. H., Lee, M. J., and Won, J. S.: Use of an artificial neural network for analysis of the susceptibility to landslides at Boun, Korea, Environ. Geology, 4, 820-833, $2003 \mathrm{a}$.

Lee, S., Ryu, J. H., Min, K., and Won, J. S.: Landslide susceptibility analysis using GIS and artificial neural network, Earth Surf. Processes Landf., 28, 1361-1376, 2003 b.

Lee, S., Ryu, J. H., Won, J. S., and Park, H. J.: Determination and application of the weights for landslide susceptibility mapping using an artificial neural network, Eng. Geol., 71, 289-302, 2004.

Lee, S., Ryu, J. H., Lee, M. J., and Won, J. S.: The Application of Artificial Neural Networks to Landslide Susceptibility Mapping at Janghung, Korea, Math. Geology, 38(2), 199-220, 2006.

Looney, C. G.: Advances in feed-forward neural networks: demystifying knowledge acquiring black boxes, IEEE Transactions on Knowledge and Data Engineering, 8(2), 211-226, 1996.

Looney, C. G.: Pattern Recognition Using Neural Networks. Theory and Algorithms for Engineers and Scientists, Oxford University Press, New York, 458 pp., 1997.

Malet, J. P., Maquaire, O., Locat, J., and Remaitre, A.: Assessing debris flow hazards associated with slow moving landslide: methodology and numerical analyses, Landslides, 1, 8390, 2004.

Malet, J. P., Laigle, D., Remaitre, A., and Maquaire, O.: Triggering conditions and mobility of debris flows associated to complex earthflows, Geomorphology, 66, 215-235, 2005.

May, C. L. and Gresswell, R. E.: Spatial and temporal patterns of debris-flow deposition in the Oregon Coast Range, USA, Geomorphology, 57, 135-149, 2004.

Messer, K. and Kittler, J.: Choosing an optimal neural network size to aid search through a large image database. Proc of 9th British 
Machine Vision Confrence (BMVC98), Univ of Southamton, UK, 235-244, 1998.

Meulenkamp, F. and Alvarez Grima, M.: Application of neural networks for the prediction of the unconfined compressive strength (UCS) from Equotip hardness, Int. J. Rock Mechanics Mining Sci., 36(1), 29-39, 1999.

Moore, I. D. and Burch, G. J.: Sediment transport capacity of sheet and rill flow: application of unit stream power theory, Water Resour. Res., 22, 1350-1360, 1986.

Moore, I. D. and Wilson, J. P.: Length-slope factors for the Revised Universal Soil Loss Equation: simplified method for estimation, J. Soil Water Conservation, 47, 423-428, 1992.

Moore, I. D., Grayson, R. B., and Ladson, A. R.: Digital terrain modeling: a review of hydrological, geomorphological, and biological applications, Hydrol. Processes, 5, 3-30, 1991.

Neaupane, K. M. and Achet, S. H.: Use of backpropagation neural network for landslide monitoring: a case study in the higher Himalaya, Eng. Geology, 74, 213-236, 2004.

Nelson, M. and Illingworth, W. T.: A Practical Guide to Neural Nets, Addisin-Wesley, Reading, MA, 352 pp., 1990.

Nemec, W. and Kazanci, N.: Quaternary colluvium in west-central Anatolia: sedimentary facies and paleoclimatic significance, Sedimentology, 46, 139-170, 1999.

Negnevitsky, M.: Artificial Inteligence: A Guide to Intelligent systems, Addison-Wesley, England, 394 pp., 2002.

Ozgul, N., Bolukbasi, S., Alkan, H., Oztas, Y., and Korucu, M.: Goller Bolgesinin Tektono-Stratigrafik Birlikleri, Ozan Sungurlu Sempozyumu Bildirileri, Ankara, p. 213-237 (in Turkish), 1991.

Paola, J. D.: Neural network classification of multispectral imagery, MSc Thesis, The University of Arizona, USA, 1994.

Rickenmann, D.: Empirical relationships for debris flows, Nat. Hazards, 19, 47-77, 1999.

Rumelhart, D. E., Hinton, G. E., and Williams, R. J.: Learning internal representation by error propogation, in: Parallel Distributed Processing, edited by: Rumelhart, D. E. and McClelland, J. L., 1, 318-362, 1986.

Sarangi, A. and Bhattacharya, A. K.: Comparison of Artificial Neural Network and regression models for sediment loss prediction from Banha watershed in India, Agric. Water Manag., 78(3), 195-208, 2005.

Scally, F. A. and Owens, I. F.: Depositional processes and particle characteristics on fans in the Southers Alps, New Zealand, Geomorphology, 69, 46-56, 2004.

Schalkoff, R. J.: Artificial Neural Network, McGraw-Hill, New York, 448 pp., 1997.
Sietsma, J. and Dow, R. J. F.: Creating artificial neural network that generalize, Neural Networks, 4, 67-69, 1991.

Singh, V. K., Singh, D., and Singh, T. N.: Prediction of strength properties of some schistose rocks from petrographic properties using artificial neural networks, Int. J. Rock Mechanics Mining Sci., 38(2), 269-284, 2001.

Sonmez, H., Gokceoglu, C., Nefeslioglu, H. A., and Kayabasi, A.: Estimation of rock modulus: for intact rocks with an artificial neural network and for rock masses with a new empirical equation, Int. J. Rock Mechanics Mining Sci., 43(2), 224-235, 2006.

Staufer, P. and Fisher, M. M.: Specral pattern recognition by a two-layer perceptron: effects of training set size, in: NeuroComputation in Remote Sensing Data Analysis, edited by: Kanellopoulos, I., Wilkinson, G. G., Roli, F., and Austin, J., Springer, London, 105-116, 1997.

Swingler, K.: Applying Neural Networks: A Practical Guide, Academic Press, New York, on CD, 1996.

Tunusluoglu, M. C., Gokceoglu, C., Nefeslioglu, H. A., and Sonmez, H.: Extraction of debris source areas by logistic regression technique: A case study from Barla, Besparmak, and Kapi Mountains (NW Taurids, Turkey), Environ. Geology, in press, doi:10.1007/s00254-007-0788-5, 2007.

Wen, B. P. and Aydin, A.: Mechanism of a rainfall-induced slidedebris flow: constrains from microstructure of its slip zone, Eng. Geology, 78, 69-88, 2005.

Wilson, J. P. and Gallant, J. C.: Terrain analysis principles and applications, John Wiley and Sons, Inc., Canada, 479 p., 2000.

Wyhthoff, B. J.: Backpropagation neural networks: a tutorial, Chemometr. Intell. Lab. Syst., 18, 115-155, 1993.

Yalcin, A.: GIS-based landslide susceptibility mapping using analytical hierarchy process and bivariate statistics in Ardesen (Turkey): Comparisons of results and confirmations, CATENA, in press, doi:10.1016/j.catena.2007.01.003, 2007.

Yesilnacar, E. and Topal, T.: Landslide susceptibility mapping: A comparison of logistic regression and neural networks methods in a medium scale study, Hendek region (Turkey), Eng. Geology, 79, 251-266, 2005.

Zhang, B. and Govindaraju, R. S.: Geomorphology-based artificial neural networks (GANNs) for estimation of direct runoff over watersheds, J. Hydrol., 273(1-4), 18-34, 2003. 